\title{
MANHAJ WAHIDUL ANAM DALAM MENULIS BUKU DEKONSTRUKSI KAIDAH 'ADALAH AL-SHAHABAH IMPLIKASINYA TERHADAP STUDI ILMU HADIS
}

\author{
Wiwin Sri Winda Sari \\ Fakultas Ushuluddin Filsafat dan Politik UIN Alauddin Makassar \\ wiwinsriwinda09@gmail.com
}

\section{Abstrak}

Adanya konsep seluruh sahabat itu adil, memunculkan perdebatan yang panjang di kalangan para ulama, karena dalam praktik kajian studi ilmu hadis, menjadi salah satu syarat diterimanya suatu hadis apabila terpenuhinya kriteria keadilan seseorang yang berhak meriwayatkan suatu hadis. Dalam pandangan Islam, sebagian ulama menganggap bahwa sahabat adalah orang yang sangat terpuji yang tidak lagi diragukan keadilannya, sedangkan sebagian yang lain menganggap bahwa tidak semua sahabat itu adil karena pada hakikatnya mereka juga adalah manusia biasa yang tidak luput dari yang namanya kesalahan dan dosa. Sebelumnya telah banyak literatur yang membahas persoalan ini, namun di luar daripada itu, penting bagi kita untuk mengkaji kembali dengan merujuk pada pemikiran dan manhaj seorang tokoh kontemporer yakni Wahidul Anam dalam bukunya dekonstruksi kaidah 'adalah alshahabah implikasinya terhadap studi ilmu hadis. Tokoh ini termasuk orang yang karyanya banyak tertuang dalam kajian keislaman, dalam kajian ilmu hadis salah satunya. Metode yang digunakan Wahidul Anam dalam bukunya ialah metode deskriptif berdasarkan kajian yang menggunakan pendekatan historis dan pendekatan teologis normatif dengan memaparkan pendapat yang ada lalu kemudian menyimpulkannya. Melalui metode itu, dapat dipahami bahwa bagaimana manhaj Wahidul Anam dalam mengembalikan kaidah seluruh sahabat itu adil pada konstruksi awalnya.

Kata Kunci: Manhaj, Wahidul Anam, Konstruksi Kaidah Keadilan Sahabat.

\section{Pendahuluan.}

Kajian kualitas para periwayat atau yang lebih dikenal 
dengan istilah 'ilm al-jarh wa al-ta'dil yang merupakan salah satu tema penting dalam ilmu hadis dan akan berakhir pada kesimpulan berhak atau tidaknya seorang periwayat itu dipercaya atau menyandang predikat adil, karena apa yang mereka riwayatkan dianggap sebagai sesuatu yang datang dari Nabi Saw dan harus diteladani dan ditaati. Dalam kajian ini, terdapat sebuah kaidah yang menyatakan kull al-shahabah hum 'udul, bahwa semua sahabat itu adil. Adil yang dimaksud ialah bahwa kualitas sahabat di sini tidak perlu lagi diteliti karena telah dianggap adil secara otomatis, sehingga hal ini mengundang perdebatan yang panjang di kalangan para ulama. ${ }^{1}$

Seiring berjalannya waktu, telaah mengenai kaidah keadilan seluruh sahabat semakin tidak menentu, di samping ada ulama yang menganggap persoalan itu telah final, masih ada pula yang melakukan revisi terhadap kaidah tersebut. Sehingga memberi pengaruh terhadap kajian hadis terutama pada menentukan kesahihan suatu hadis. Dengan adanya perbedaan yang seperti ini, maka perlunya untuk didiskusikan kembali dengan mendekonstruksikan kaidah tersebut dan implikasinya terhadap kajian ilmu hadis. Dalam persoalan ini, Wahidul Anam menggunakan metode deskriptif dengan mengungkap pendapat-pendapat yang ada lalu kemudian diberikan kesimpulan berdasarkan pemahamannya. ${ }^{2}$

Pendekatan yang digunakan Wahidul Anam dalam membongkar kaidah keadilan sahabat ialah menggunakan pendekatan Teologis-Normatif dan pendekatan sejarah. Adapun yang dimaksud dengan pendekatan Teologis-Normatif adalah

1Wahidul Anam, Dekonstruksi Kaidah 'Adalah al-Shahabah Implikasinya Terhadap Studi Ilmu Hadis, (Cet. I; Yogyakarta: PT Lkis Printing Cemerlang, 2016), h. 1.

2Wahidul Anam, Dekonstruksi Kaidah 'Adalah al-Shahabah Implikasinya Terhadap Studi Ilmu Hadis, h. 8. 
suatu pendekatan yang memandang agama dari segi ajarannya yang pokok dan asli dari Tuhan yang di dalamnya belum terdapat penalaran pemikiran manusia. Dalam pendekatan ini, agama dilihat sebagai suatu kebenaran mutlak dari Tuhan. Pendekatan Normatif dapat juga dikatakan pendekatan yang bersifat domain keimanan tanpa melakukan kritis kesejarahan yang berkembang, serta tidak memperhatikan konteks kesejarahan Alquran, hadis, dan teks-teks keagamaan lainnya. Pendekatan ini mengasumsikan seluruh ajaran Islam, baik yang terdapat dalam Alquran, hadis, maupun ijtihad sebagai suatu kebenaran yang harus diterima dan tidak boleh digugat lagi.

Pendekatan teologis-normatif dalam pemahaman keagamaan adalah pendekatan yang menekankan pada bentuk forma atau simbol-simbol keagamaan masing-masing bentuk forma atau simbol-simbol keagamaan tersebut mengklaim dirinya sebagai yang paling benar sedangkan yang lainnya sebagai salah. Aliran teologi yang satu begitu yakin dan fanatik bahwa pahamnyalah yang benar sedangkan paham lainnya salah, sehingga memandang paham orang lain itu keliru, sesat, kafir, murtad dan seterusnya demikian pula sebaliknya. Sehingga terjadilah proses saling mengkafirkan, saling menyalahkan dan seterusnya. Terjadinya sikap tertutup antara satu dengan yang lainnya, hilangnya keterbukaan sehingga menjadikan mereka terpisah dan berkotak-kotak. ${ }^{3}$

Selain menggunakan pendekatan teologis-normatif, juga digunakan pendekatan sejarah. Sejarah sebagai suatu pendekatan dan metodologi dapat mengembangkan pemahaman berbagai gejala dalam dimensi waktu, dalam hal ini

3Wahidul Anam, Dekonstruksi Kaidah 'Adalah al-Shahabah Implikasinya Terhadap Studi IImu Hadis, h. 225-226. 
aspek kronologis merupakan ciri khas dalam mengungkapkan suatu gejala agama. Konsekuensi pendekatan sejarah dalam penelitian terhadap gejala-gejala agama haruslah dilihat dari segi-segi prosedural dan perubahan-perubahan. Pendekatan sejarah dalam studi Islam merupakan pengkajian fenomena historis dari masyarakat Muslim. Pembongkaran kaidah "seluruh sahabat adil" juga tidak lepas dari pendekatan sejarah. Para pemikir Islam yang membongkar kaidah ini menggunakan pendekatan sejarah untuk: pertama, memahami doktrin-doktrin teks keagamaan, baik dari Alquran maupun hadis. kedua, untuk menjelaskan realitas perilaku sahabat yang sesungguhnya. ${ }^{4}$

\section{Biografi Wahidul Anam}

Dr. Wahidul Anam, M. Ag, lahir di Blitar, 6 Februari 1974. Setelah menyelesaikan pendidikan dasarnya di Kepanjen Lor IV Kota Blitar (1987), Sekolah Menengah di SMPN III Blitar (1990), dan STMN Blitar (1993) kemudian melanjutkan pendidikan tingginya di STAIN Malang Jurusan Pendidikan Bahasa Arab (1999), pascasarjana di IAIN Sunan Ampel Surabaya (2001), dan program doktor di UIN Sunan Kalijaga (2014). Selain itu, ia juga mengikuti pendidikan non-formal di Madrasah Diniyyah Tarbiyatul Muballighin Sukorejo Kota Blitar, tahun 1987-1999 dan di Pondok Pesantren Nurul Huda Malang, tahun1993-1999.

Dr. Wahidul Anam juga aktif di organisasi sosialkemasyarakatan, di antaranya pernah menjadi Ketua Cabang Lembaga Pendidikan Ma'arif NU Kota Blitar periode 2011-2016, Sekretaris Dewan Pendidikan Kota Blitar periode 2008-2013, Ketua Bidang Penelitian dan Pengembangan MUI (Majelis Ulama Indonesia) Kota Blitar periode 2011-2016, Ketua Yayasan

${ }^{4}$ Wahidul Anam, Dekonstruksi Kaidah 'Adalah al-Shahabah Implikasinya Terhadap Studi Ilmu Hadis, h. 230-231. 
Pondok Pesantren Bustanul Muta'alimat Kota Blitar, periode 2011-2016, IKAPMII Blitar periode 2010-2014, Wakil Katib Syuriyah NU Cabang Kota Blitar periode 2006-2011, Ketua Seksi Pendidikan Masjid Agung Kota Blitar periode 2011-2015, dan Wakil Ketua GP Ansor Cabang Kota Blitar periode 2006-2010.

Saat ini Dr. Wahidul Anam adalah dosen di STAIN Kediri sejak 2003, juga menjadi dosen di STKIP PGRI Blitar sejak 2006, dosen dengan tugas tambahan sebagai Ketua Program Studi Pendidikan Bahasa Arab periode 2006-2010, dosen dengan tugas tambahan sebagai Ketua Program Studi Pendidikan Agama Islam periode 2010-2014, dan dosen dengan tugas tambahan sebagai Ketua Pusat Penelitian Dan Pengabdian Masyarakat STAIN Kediri periode 2015-2019.

Buku yang telah dipublikasikan di antaranya ialah, Implementasi Pendidikan Sains Dalam Lembaga Pendidikan Islam (editor, 2010). Sementara penelitian yang telah dihasilkan antara lain: "Hadis Baht al- Masa'il Nahdhatul Ulama Tahun 1985-1995 (Studi Kritik Sanad dan Matn Hadis) (2001); "Pluralisme Agama dalam Pandangan Pimpinan Ormas dan Parpol Islam di Kota Blitar" (2008); "Perilaku Sahabat Nabi Muhammad Saw dalam Alquran dan Implikasinya Terhadap Penilaian Seluruh Sahabat Adil dalam Studi Hadis" (2012); "Hadis dalam Kitab Al-Halal Wa Al-Haram Fi al- Islam Karya Yusuf Qardawiy (Studi Kritik Autentisitas Sanad Hadis)” (2013); 'Adalah al-Sahabah dalam Studi Hadis (Kemunculan, Pelembagaan, dan Pembongkaran) (2014); dan Pemikiran Mahmud Abu Rayyah Dalam Kitab "Adwa' 'Ala al-Sunnah alMuhammadiyah" Dan Implikasinya Terhadap Teori Studi Hadis Klasik (2014). Sedangkan artikel-artikelnya adalah "Mengkaji Ulang Tafsir Alquran dan al-Hadis Tentang Keadilan Sahabat," (Jurnal Empirisma STAIN Kediri, 2007); "Penerapan Hukum 
Perang: Telaah Sosio-Historis dengan Pendekatan Tafsir Maudhu'i (Jurnal TRIBAKTI, 2005); “Kriteria Hadis Shahih: Perspektif Sunni dan Syi'ah" (Jurnal Empirisma, 2011); dan "Metodologi Pemikiran Islam Liberal dan Islam Fundamental: Pemikiran Ulil Abshar Abdalla dan Hartono Ahmad Jaiz (Jurnal Empirisma, 2007).

Saat ini, jabatan struktural Dr. Wahidul Anam adalah Lektor Kepala yang bertempat tinggal di Jl. Kapuas No. 20 Kota Blitar Jawa Timur, bersama dengan istri tercinta, Ni'matul Umamah, A. Md., dan ketiga anaknya; Salma Labibah Wahid, Alya Zidanil Ilma Wahid, dan Nabilul Hikam al-Hadhiq Wahid. (lihat di buku dekonstruksi kaidah 'adalah al-shahabah implikasinya terhadap studi ilmu hadis) ${ }^{5}$

\section{Definisi Keadilan Sahabat}

a. Pengertian 'Adalah (adil)

Secara harfiah kata 'Adalah dapat diartikan sebagai keadilan. 6 Dalam kamus besar bahasa Indonesia, kata adil berarti tidak berat sebelah, adil adalah kata dasar dari kata keadilan yang merupakan kata sifat (perbuatan, perlakuan dan sebagainya). ${ }^{7}$

Keadilan berasal dari bahasa Arab yang terambil dari kata العَدْلُ yang berarti sesuatu yang terdapat dalam jiwa bahwa sesuatu itu lurus dan merupakan antonim dari kata tidak wajar. العَدْلُ terambil dari huruf $J-\mathcal{L}$, , rangkaian huruf ini mempunyai dua makna "sama dan lurus" dan "bengkok" dan

${ }^{5}$ Wahidul Anam, Dekonstruksi Kaidah 'Adalah al-Shahabah Implikasinya Terhadap Studi Ilmu Hadis, h. 287-289.

${ }^{6}$ WahidulAnam, Dekonstruksi Kaidah 'Adalah al-Shahabah Implikasinya Terhadap Studi Ilmu Hadis, h. 53.

7Tim Pustaka Phoenix, Kamus Besar Bahasa Indonesia, (Cet 5; Jakarta Barat: PT Media Pustaka Phoenix, 2010), h. 9. 
"berbeda".

Sedangkan menurut istilah, ulama berbeda-beda pendapat dalam mendefinisikan "adil". Menurut Abu Syu'bah, yang dimaksud dengan adil adalah watak dan sifat yang sangat kuat dan mampu mengarahkan orang untuk bertakwa, menjauhi perbuatan mungkar dan segala sesuatu yang merusak sifat. Sedangkan menurut Ibnu Hajar, seseorang dapat dikatakan adil apabila memenuhi syarat; takwa, memelihara muru'ah, bebas dari dosa besar, tidak melakukan bid'ah dan tidak fasik. Ibnu Salah juga memberikan kriteria seseorang dapat dikatakan adil apabila; muslim, balig, berakal, selamat dari hal-hal yang menyebabkan kefasikan dan memelihara muru'ah. Sedangkan al-Hakim berpendapat bahwa seseorang disebut adil apabila beragama Islam, tidak berbuat bid'ah, dan tidak berbuat maksiat.

Berdasarkan pernyataan para ulama di atas, dapat disimpulkan berbagai kriteria seorang periwayat dinyatakan adil, ialah: 1) Beragama Islam. 2) Balig. 3) Berakal. 4) Bertakwa. 5) Memelihara Muru'ah. 6) Teguh dalam beragama. 7) Tidak berbuat dosa besar. 8) Tidak berbuat maksiat. 9) Tidak berbuat bid'ah. 8

Berdasarkan analisis M. Syuhudi Ismail dalam memberikan definisi keadilan pada periwayat, maka pendapatpendapat para ulama diikhtisarkan dan dibatasi hanya berasal dari lima belas orang ulama di berbagai zaman. Dari kelima belas ulama ini, sepuluh orang di antaranya dikenal sebagai ulama hadis, di samping juga di antara mereka ada yang dikenal di bidang ilmu keislaman tertentu lainnya. Kelima orang ulama

${ }^{8}$ Bukhari Muslim, Dari Keadilan Sahabat Dan Kemaksuman Imam Hingga Validitas Hadis: Kajian Paradigma Dua Mazhab Besar Islam, (cet 1; Makassar: Lembaga Ladang Kata, 2018), h. 39-41. 
selebihnya dikenal sebagai ulama Ushul al-Fiqh atau Fiqh, di samping juga dikenal di bidang ilmu keislaman tertentu lainnya. ${ }^{9}$ Pada prinsipnya kriteria keadilan terdiri dari empat butir, yaitu: 1) Beragama Islam. Kriteria ini tidak berlaku dalam proses penerimaan riwayat, berarti bahwa orang menerima suatu riwayat boleh saja dalam keadaan sedang tidak memeluk agama Islam. Namun, apabila hendak meriwayatkan apa yang diterimanya maka sepatutnya ia telah memeluk agama Islam. 2) Mukallaf. Yakni baligh dan berakal. Untuk penerimaan riwayat, periwayat tersebut boleh saja masih belum Mukallaf, asal saja ia telah mumayyiz (dapat memahami maksud pembicaraan dan dapat membedakan antara sesuatu dengan sesuatu yang lain). Jadi, seorang anak yang menerima suatu riwayat kemudian setelah Mukallaf riwayat itu disampaikan kepada orang lain, maka penyampaian riwayat tersebut telah memenuhi salah satu kriteria keshahihan sanad hadis. 3) melaksanakan ketentuan agama. Yang dimaksud ialah teguh dalam agama, tidak berbuat dosa besar, tidak berbuat bid'ah, tidak berbuat maksiat, dan harus berakhlak mulia. 4) memelihara muru'ah. Ialah kesopanan pribadi yang membawa pemeliharaan diri manusia pada tegaknya kebajikan moral dan kebiasaan-kebiasaan. ${ }^{10}$

Menurut Jalal al-Din al-Syuyuthi, setidaknya ada enam makna yang bisa diterapkan bagi kata 'Adalah dari segi bahasa. Pertama, berarti lawan dari kecurangan dan kezaliman, misalnya kata yang ditujukan bagi seorang raja "ia seorang yang adil". Kedua, berarti lawan dari kefasikan dan kemaksiatan. Ketiga, berarti terpelihara, maksudnya memiliki kualitas diri

${ }^{9}$ M. Syuhudi Ismail, Kaedah Keshahihan Sanad Hadis, Telaah Kritis dan Tinjauan dengan Pendekatan Ilmu Sejarah, (Cet 2; Jakarta: PT Bulan Bintang, 1995), h. 129.

10M. Syuhudi Ismail, Metodologi Penelitian Hadis Nabi, (Cet 1; Jakarta: Bulan Bintang, 1992), h. 67-68. 
yang terhindar dari kekejian, kemaksiatan sebagaimana para Nabi dan Malaikat. Keempat, berarti terjaga dari dosa dan kesalahan sebagai karunia dari Allah Swt tanpa diupayakan sebagaimana sifat para auliya'. Kelima, berarti terjaga dari kesalahan dalam berijtihad sebagaimana sebagian ulama syi'ah menyebut kualitas ini pada Sang Mahdi yang ditunggu. Keenam, berarti terhindar dari kebohongan dan sikap berlebihan yang disengaja dalam periwayatan dengan melakukan sesuatu yang menyebabkan tidak diterima perkataannya.

Secara terminologis, al-Ghazali mendefinisikan 'adalah sebagai suatu ungkapan tentang istiqamahnya perjalanan hidup dan kehidupan beragama. Menurut Ibn Mubarak, ada lima kriteria seseorang dikatakan sebagai orang yang adil, yakni pengakuan masyarakat, tidak minum-minuman keras, tidak ada cela dalam urusan agamanya, bukan seorang pembohong, dan tidak ada sesuatu dalam akalnya.

Salah seorang ahl al-Bayt Nabi, yaitu Ali Ridha bin Musa al-Kazim, mendefinisikan adil sebagai siapa saja yang berkata kepada manusia dan tidak membohonginya, siapa saja yang berjanji kepada manusia dan tidak mengingkarinya, maka dialah yang sempurna kehormatannya dan tampak jelas keadilannya.

Al-Baqilani mendefinisikan 'adalah sebagai predikat seseorang yang istiqamah dalam agamanya, lurus mazhabnya, selamat dari kefasikan dan apa yang secara adat dianggap membatalkan keadilan, baik dari perilaku kahir maupun perilaku batin. Ibn Hazm mendefinisikan adil dengan sangat ringkas, yaitu orang yang tidak diketahui pernah berbuat dosa besar atau terang-terangan melakukan dosa besar.

Dari berbagai definisi 'adalah yang dikemukakan para pemikir Islam di atas, Wahidul Anam menyimpulkan bahwa 'adalah merupakan suatu kualitas kepribadian seseorang yang 
berasal dari sikap takwa dan memelihara kehormatan diri, di mana kualitas ini dapat dilihat secara lahiriah dari pemeliharaan diri dari dosa besar dan kebiasaan melakukan dosa kecil serta hal-hal kecil namun merusak harga diri, seperti makan sambil berjalan, kencing di tempat terbuka, dan yang sejenisnya. ${ }^{11}$

b. Pengertian al-Shahabah

Dalam bahasa Arab, الصَّحَابَة merupakan bentuk jamak

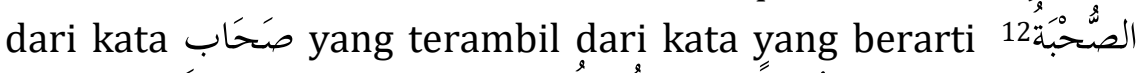

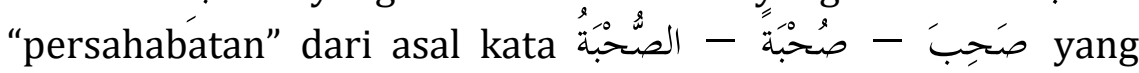
berarti "menemani".13

Dalam kamus besar bahasa Indonesia, sahabat berarti teman atau kawan. Bersahabat berarti berteman, dalam artian sahabat Nabi Muhammad Saw terutama: Abu Bakar, Umar, Utsman; sahabat Nabi Isa, murid Nabi Isa yang pertama-tama 12 orang banyaknya. Persahabatan berarti persaudaraan, perhubungan selaku sahabat. Dan mempersahabatkan berarti menjadikan sahabat (supaya berteman) memperkenalkan supaya bersahabat. ${ }^{14}$

Menurut Jumhur ahli hadis, sahabat ialah:

Artinya:

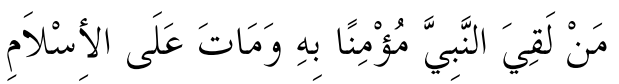

"Orang yang bertemu dengan Nabi, ia beriman kepadanya dan mati dalam keadaan Islam, (di masa Nabi masih

11Wahidul Anam, Dekonstruksi Kaidah 'Adalah al-Shahabah Implikasinya Terhadap Studi Ilmu Hadis, h. 53-55.

12Syaikh Manna' al-Qaththan, Pengantar Studi Ilmu Hadis, (Cet 9; Jakarta Timur: Pustaka al-Kautsar, 2016), h. 77.

${ }^{13}$ Ahmad Warson Munawwir, Al-Munawwir Kamus Arab-Indonesia, (Cet 14; Surabaya: Pustaka Progressif, 1997), h. 763-764.

14Tim Pustaka Phoenix, Kamus Besar Bahasa Indonesia, (Cet 5; Jakarta Barat: PT Media Pustaka Phoenix, 2010), h. 729. 
hidup)."15

Wahidul Anam dalam bukunya menjelaskan definisi sahabat dengan merujuk pada berbagai referensi kemudian mengelompokkan definisi sahabat menjadi dua kelompok, yakni kelompok pertama definisi yang ketat terhadap sahabat, dan kedua adalah definisi yang longgar terhadap sahabat.

Adapun pendapat yang dikutip dalam buku karangan Wahidul Anam yang memberikan definisi ketat dalam menyandang predikat sebagai seorang sahabat ialah Anas bin Malik yang membedakan antara ra'a dan shahiba yakni seseorang dianggap sebagai seorang sahabat apabila ia bukan saja pernah melihat Nabi Saw melainkan juga "bersahabat" atau menjalin persahabatan dengan Nabi Saw. Ketika Anas bin Malik ditanya oleh Musa al-Sablani "Apakah masih ada sampai saat ini sahabat Nabi yang masih hidup selain Anda?" kemudian Anas bin Malik menjawab, "masih ada orang A'rabi (Badui) yang telah melihat Nabi sebenarnya, sedangkan yang bersahabat dengan Nabi telah tidak ada”. Definisi yang dikemukakan oleh Anas yang sedemikian ketat menyebabkan banyak orang gugur predikatnya sebagai sahabat, apalagi orang yang masuk Islam pada masa Nabi dan ia belum pernah sama sekali bertemu atau bersahabat dengan Nabi.

Sa'id bin Musayyab seorang pemikir muslim pada masa awal juga memberikan definisi yang ketat perihal predikat sahabat terhadap seseorang, yakni orang yang dianggap sebagai sahabat adalah orang yang bersama dengan Nabi Saw selama satu atau dua tahun dan juga ikut berperang bersama Nabi baik sekali maupun dua kali. Dari definisi ini, Sa'id bin Musayyab

15Teungku Muhammad Hasbi Ash-Shiddieqy, Sejarah \& Pengantar Ilmu Hadis, (Cet 2; Semarang: PT Pustaka Rizki Putra, 2009), h. 206. 
tidak hanya mensyaratkan melihat atau ru'yah dan shuhbah, tetapi ada persyaratan waktu yang harus mengikuti kegiatan penting, paling tidak sekali, yang dilakukan bersama Nabi. Kata yang digunakan Sa'id bin Musayyab adalah aqama, dan definisi tampaknya lebih berat dari definisi Anas bin Malik.

Definisi yang ketat terhadap sahabat juga dikemukakan oleh Ulama' Ushul. Menurut Ibnu Tayyib al-Bashriy, salah satu Ulama'Ushul, menyatakan bahwa seseorang dinyatakan sebagai seorang sahabat paling tidak harus memenuhi dua hal. Pertama, orang tersebut harus lama bersama Nabi. Kedua, mengikuti perilaku Nabi. Apabila orang tersebut lama bersama Nabi namun tidak berniat untuk mengikuti Nabi maka orang tersebut tidak termasuk dalam kategori sahabat Nabi. Ulama' Ushul yang lain adalah Ibn al-Shabagh. Ia mendefinisikan sahabat sebagai orang yang bertemu dengan (laqiya), hidup bersama (agama), dan mengikuti (ittaba'a) Nabi Saw. demikian juga al-Kiya' alTabari mendefinisikan sahabat sebagai orang yang tampak persahabatannya dengan Nabi Saw. sebagaimana persahabatan seorang teman dengan temannya sehingga dia dihitung (dimasukkan) dalam anggotanya. Ibnu al-Furra', salah seorang Ulama' Ushul menyatakan bahwa sahabat adalah orang yang banyak bersama sahabat dengan Nabi dan kebersamaan yang khusus dengannya. Ulama' Ushul lain yang mendefinisikan sahabat adalah al-Mudhaffar al-Sam'ani. Menurutnya, sahabat dari sisi kebahasaan adalah orang yang lama bersama dengan Nabi dan mengikuti majelis-majelisnya kemudian mengambil darinya. Selanjutnya menurut al-Sam'ani, para ahli hadis mendefinisikan sahabat adalah setiap orang yang meriwayatkan satu hadis atau satu kalimat saja, selanjutnya para ahli hadis memperluas makna sahabat sampai pada pengertian siapa saja yang melihat Nabi Saw juga dihitung sebagai sahabat. Dari 
uraian di atas, jelaslah bahwa Ulama'Ushuliyyun mendefinisikan sahabat sebagai orang yang telah lama hidup bersama Nabi, mengikuti majelis-majelisnya, mengikuti dan menerima hadis dari Nabi Saw.

Seorang ulama yang dianggap kontroversial, bahkan banyak dicela oleh ahli hadis pada masanya adalah al-Waqidi, juga mendefinisikan sahabat secara ketat. Menurutnya, sahabat adalah setiap orang yang melihat Nabi, sedangkan dia dalam keadaan baligh, muslim, mengerti urusan agama dan ia rela dengannya. Dari definisi ini, ada pendapat yang berbeda yakni pada syarat Aqil-Baligh, dan pendapat ini ditentang oleh al-'Iraqi sebab syarat ini akan mengeluarkan Ibnu 'Abbas, Hasan, Husein, dan Ibnu Zubayr dari kategori sahabat.

Pemikir Islam modern yang mendefinisikan sahabat secara ketat adalah Hassan Hanafi. Menurutnya, sahabat bukan hanya mereka yang telah bertemu dengan Nabi Muhammad Saw, tetapi harus ada syarat lain yang harus dipenuhi yaitu mereka harus mengamalkan Alquran. Karena tolak ukur dari Hassab Hanafi ialah bukan hanya sekedar hubungan kekerabatan atau pertalian darah, melainkan juga berdasarkan perbuatan dan ini berlaku untuk siapa saja, termasuk keluarga Nabi Saw. Itulah beberapa definisi sahabat secara ketat yang memungkinkan beberapa orang dapat dikategorikan sebagai seorang sahabat.

Selanjutnya akan dipaparkan definisi menyandang predikat sahabat secara longgar. Ahmad bin Hanbal salah seorang pemikir Islam klasik yang pertama memberikan definisi secara longgar terhadap sahabat. Menurutnya, sahabat ialah setiap orang yang bersahabat dengan Nabi baik sehari, sebulan, sesaat atau bahkan hanya melihatnya. Berbeda dengan pendapat-pendapat sebelumnya, Ahmad bin Hanbal tidak 
memberikan syarat seseorang terhadap predikat sahabat melainkan hanya bersahabat atau hanya melihatnya saja. Hal ini sejalan dengan pendapat al-Bukhari. Menurutnya, seseorang dapat dianggap sebagai seorang sahabat ketika orang itu beragama Islam dan melihat Nabi Saw, di sini juga al-Bukhari tidak memberikan syarat sebagaimana pendapat yang ada sebelumnya.

Adapun definisi yang umum dipakai oleh para ulama hadis adalah definisi yang dikemukakan oleh Ibnu Hajar al'Asqalani al-Shafi'i. Menurutnya, sahabat ialah orang yang bertemu dengan Nabi Saw, beriman kepada Nabi dan meninggal dalam keadaan Islam. Dengan demikian, yang termasuk sahabat ialah mereka sempat bertemu dengan Nabi Saw yang:1) menerima dakwahnya dalam waktu lama atau sebentar; 2) meriwayatkan hadis dari Nabi Saw ataupun tidak meriwayatkannya; 3) ikut berbaiat pada Nabi Saw. atau tidak; 4) sempat melihat Nabi Saw meskipun tidak pernah duduk menemani, atau tidak pernah melihat Nabi Saw karena sebab tertentu (seperti orang buta).

Ibnu Salah mendefinisikan sahabat dengan mengikuti definisi yang sudah dikenal dalam studi hadis seperti Ibnu Hajar al-'Asqalani, yaitu setiap muslim yang melihat Nabi. Adapun definisi yang menurut Wahidul Anam adalah kontroversial adalah definisi sahabat yang dikemukakan oleh Yahya bin 'Utsman bin Shalih al-Mishri. Menurutnya, sahabat sebagai orang yang semasa dengan Nabi Saw.

Dari dua kelompok definisi di atas, maka Wahidul Anam menyimpulkan bahwa untuk mencapai predikat sebagai seorang sahabat, paling tidak seseorang harus memiliki 7 kriteria di bawah ini:

1) Orang yang semasa dengan Nabi Saw, beragama 
Islam, walaupun tidak melihat Nabi Saw.

2) Orang yang baligh, beragama Islam, berakal, rela terhadap Nabi, dan melihatnya walaupun sesaat di siang hari.

3) Orang yang melihat Nabi dengan syarat lama bersamanya dan mengambil ilmu darinya.

4) Orang yang bersama dengan Nabi selama satu atau dua tahun dan ikut berperang bersama Nabi, baik sekali maupun dua kali.

5) Orang yang lama bersama Nabi, mengikuti majelis-majelisnya dan mengambil ilmu darinya.

6) Orang yang bertemu dengan Nabi, beriman kepadanya dan meninggal dalam keadaan Islam.

7) Mereka bertemu Nabi dan mengamalkan Alquran. ${ }^{16}$

\section{Perumusan Konsep Kaidah Keadilan Sahabat Sampai Pada Pembongkaran Kaidah keadilan Sahabat}

Dalam mengungkap problematika 'adalah pada masa Nabi Saw dan sahabat, Wahidul Anam dalam bukunya mengangkat berbagai contoh persoalan yang terjadi pada masa itu. Adapun persoalan yang diangkat beberapa di antaranya ialah meliputi persoalan landasan teologis para sahabat, di mana beberapa sahabat Nabi Saw tidak begitu saja menerima riwayat sahabat yang lain, bahkan ada beberapa di antara mereka yang menolak riwayat sahabat yang lain. Salah satu kasus penolakan riwayat seorang sahabat oleh sahabat yang lain ialah kasus 'Aishah. Ibn Qutaybah menyatakan bahwa 'Aishah merupakan orang yang paling penuh semangat di antara para sahabat yang

16Wahidul Anam, Dekonstruksi Kaidah 'Adalah al-Shahabah Implikasinya Terhadap Studi Ilmu Hadis, h. 27-38. 
mengingkari Abu Hurairah, karena keduanya berhubungan dekat satu sama lain selama bertahun-tahun. Mungkin, karena hubungan yang begitu dekat, 'Aishah sangat memahami karakter Abu Hurairah. ${ }^{17}$ Adapun salah satu hadis yang diingkari oleh 'Aishah adalah sebagai berikut:

Artinya:

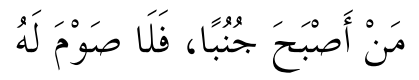

"Barang siapa bangun di pagi hari (selama bulan Ramadhan) dalam keadaan hadas besar, maka puasanya sia-sia."18

Hadis di atas mempunyai banyak versi, tetapi intinya sama dan 'Aishah selalu menyampaikan kebiasaan Nabi Muhammad Saw, bahwa ketika Nabi Saw berhadas besar tanpa bermimpi pada bulan Ramadhan dan masuk waktu subuh, Nabi mandi besar dan melanjutkan puasanya. Tentu apa yang disampaikan 'Aishah ini bertentangan dengan apa yang diriwayatkan oleh Abu Hurairah.

Ketika 'Aishah memberikan pernyataan yang berbeda dengan apa yang disampaikan oleh Abu Hurairah, bahkan Umm Salamah juga mendukung pernyataan 'Aishah, Abu Hurairah berkilah bahwa apa yang diriwayatkannya tidak didengarnya langsung dari Nabi Saw, tetapi dari al-Fadl bin 'Abbas dan alNasa'i menyatakan bahwa Abu Hurairah menerima hadis ini dari Abu Usamah bin Zayd. Jika benar bahwa riwayat Abu Hurairah ini dari al-Fadl bin 'Abbas dan Usamah bin Zayd dari Nabi, maka kritik 'Aishah sebenarnya tidak berhenti pada Abu Hurairah saja, melainkan kredibilitas al-Fadl bin 'Abbas dan Usamah bin

${ }^{17}$ Wahidul Anam, Dekonstruksi Kaidah 'Adalah al-Shahabah Implikasinya Terhadap Studi Ilmu Hadis, h. 71.

${ }^{18} \mathrm{Ahmad}$ bin Abdurrahman bin Muhammad, al-Fathu ar-Ribani Musnad al-Imamu ahmad bin Hanbal, (Cet 2; Arab: Ihya al-Turasi, t.t), h. 67. 
Zayd juga dipertanyakan.

Berdasarkan kejadian di atas, dan masih ada beberapa hadis lagi yang disebutkan di dalam buku karangan wahidul Anam atas terjadinya kritik antara satu sahabat dengan sahabat yang lainnya menandakan bahwa problematika keadilan pada masa Nabi dan sahabat ialah adanya kritik antara sahabat dengan sahabat yang lain dari periwayatan hadis Nabi Muhammad Saw. ${ }^{19}$

Pemikiran perumusan kaidah 'adalah al-shahabah pada masa klasik bukan berarti tanpa masalah. Tantangan yang mereka hadapi terutama dari kaum Mu'tazilah, karena pada masa klasik, eksistensi kaum Mu'tazilah sangat menonjol, sehingga ahli hadis klasik mengalami banyak kendala dalam menegakkan hadis sebagai bagian dari ajaran agama Islam. Isu utama yang menjadi dasar perkembangan perumusan kaidah ini berpijak pada peristiwa-peristiwa politik yang terjadi pada masa sahabat. Dalam kasus terbunuhnya khalifah Utsman bin Affan misalnya. ${ }^{20}$

Berdasarkan penjelasan Wahidul Anam dalam bukunya "Dekonstruksi Kaidah 'Adalah al-Shahabah Implikasinya Terhadap Studi Ilmu Hadis" mengenai hal yang menjadi motif dalam merumuskan kaidah keadilan sahabat paling tidak ada tiga motif, yakni pemikiran keagamaan, politik dan aliran keagamaan yang muncul dan berkembang pada masa itu. Sebelum membahas lebih lanjut mengenai motivasi perumusan kaidah keadilan sahabat, Wahidul Anam terlebih dahulu menjelaskan makna motivasi, di mana istilah motivasi (motivation) berasal dari bahasa Latin, yaitu movere yang

${ }^{19}$ Wahidul Anam, Dekonstruksi Kaidah 'Adalah al-Shahabah Implikasinya Terhadap Studi Ilmu Hadis, h. 71-74.

${ }^{20}$ Wahidul Anam, Dekonstruksi Kaidah 'Adalah al-Shahabah Implikasinya Terhadap Studi Ilmu Hadis, h. 84. 
berarti "menggerakkan" (to move). Motif (motiv) atau dorongan adalah suatu pendorong yang dapat mendorong manusia untuk melakukan suatu tindakan dorongan (tenaga) atau suatu pendorong tersebut merupakan penggerak hati (jiwa) ataupun jasmani untuk bertindak atau berbuat sesuatu yang melatarbelakangi manusia untuk berbuat sesuatu untuk mencapai keinginannya (tujuannya). Menurutnya, motif merupakan sesuatu yang melatarbelakangi manusia segala aktivitas dan motif ini bisa berasal dari luar dan dari dalam manusia itu sendiri.

Adapun motif yang termasuk dalam kategori Wahidul Anam dalam perumusan kaidah keadilan sahabat ialah, sebagai berikut:

1) Pemikiran keagamaan, perumusan kaidah bahwa semua sahabat adil tidak terlepas dari berkembangnya pemikiran keagamaan umat Islam yang terpecah belah menjadi berbagai macam sekte, yang akan berujung pada pentingnya menempatkan jaran agama Islam pada eksistensinya. ${ }^{21}$

2) Politik dan aliran keagamaan, perumusan kaidah keadilan sahabat juga tidak terlepas dari perkembangan politik dan aliran-aliran keagamaan. Pada masa awal, terjadi kritik antara seorang sahabat dengan sahabat yang lain dan permintaan persaksian antar sahabat. Pergolakan politik yang terjadi terbukti saat terjadinya perebutan kekuasaan antara 'Ali, Mu'awiyah, dan sekte khawarij yang kemudian melahirkan berbagai aliran dalam Islam. ${ }^{22}$

${ }^{21}$ Wahidul Anam, Dekonstruksi Kaidah 'Adalah al-Shahabah Implikasinya Terhadap Studi Ilmu Hadis, h. 86-88. 
Berdasarkan motif dan problematika yang disebutkan di atas mengenai konsep keadilan sahabat, Wahidul Anam dalam bukunya mengungkap pembongkaran kaidah keadilan sahabat dengan merujuk pada 3 pokok pemikiran yakni perspektif kaum Syi'ah, perspektif Ahmad Amin dan perspektif Mahmud Abu Rayyah.

Kaum Syi'ah yang dikenal sebagai pengikut dan pendukung khalifah 'Ali bin Abi Thalib yang menurut mereka berhak menjadi khalifah setelah Nabi Saw, berdiri atas doktrin yang kuat dikenal dengan doktrin Imamah dan 'Isymah yang di mana doktrin ini kemudian akan memberikan implikasi pada penilaian Syi'ah terhadap kaidah keadilan sahabat. ${ }^{23}$ Adapun landasan teologi kaum Si'ah dalam memperkuat konsep Imamah ialah berdasarkan dalil Alquran surah al-Baqarah ayat 124, sebagai berikut:

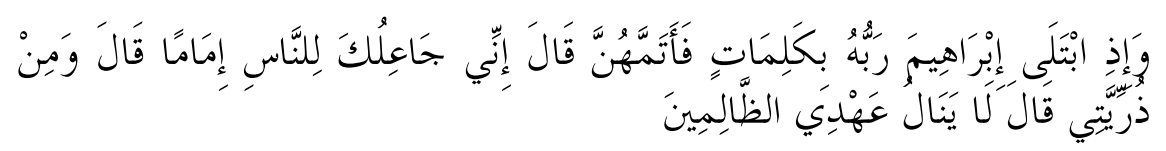

Artinya:

"Dan (ingatlah), ketika Ibrahim diuji Tuhannya dengan beberapa kalimat, lalu dia melaksanakannya dengan sempurna. Dia (Allah) berfirman, "Sesungguhnya Aku menjadikan engkau sebagai pemimpin bagi seluruh manusia." Dia (Ibrahim) berkata, "Dan juga anak cucuku?" Allah berfirman, "(Benar, tetapi) janji-ku tidak berlaku bagi orang-orang yang zalim."24

22Wahidul Anam, Dekonstruksi Kaidah 'Adalah al-Shahabah Implikasinya Terhadap Studi Ilmu Hadis, h. 98.

${ }^{23}$ Wahidul Anam, Dekonstruksi Kaidah 'Adalah al-Shahabah Implikasinya Terhadap Studi Ilmu Hadis, h. 148. 
Adapun untuk mendukung konsep Imamah maka perlu adanya konsep 'Isymah, yang berarti pemeliharaan Allah terhadap hamba-hambanya dari keburukan yang akan menimpanya dan hamba itu berpegang teguh kepada Allah sehingga ia tercegah dan terlindungi. Dalam hal ini, menurut Syi'ah khalifah 'Ali bin Abi Thalib yang lebih tepat memiliki kriteria yang disebutkan sehingga 'Ali bin Abi Thalib yang seharusnya diangkat menjadi khalifah setelah Nabi Saw. Sehingga kaum Syi'ah menolak adanya konsep adil pada seluruh sahabat karena menurut mereka konsep Imamah dan 'Isymah yang memberi argumen bahwa seluruh Ahl al-Bait itu adil.25

Selanjutnya konsep keadilan sahabat perspektif Ahmad Amin. Dalam pandangannya, diungkapkan bahwa telah terjadi kritik antar sahabat pada masanya, sehingga dalam periwayatan diperlukan adanya persaksian. Sehingga dapat disimpulkan bahwa Ahmad Amin dalam pandangannya di atas juga menolak adanya kaidah keadilan seluruh sahabat. ${ }^{26}$

Adapun pembongkaran kaidah keadilan sahabat perspektif Mahmud Abu Rayyah diungkapkan bahwa kritik yang dilontarkan kepada Abu Hurairah begitu banyak dijelaskan dalam buku karangan Wahidul Anam. Salah satu kritikannya ialah bahwa Abu Hurairah memeluk Islam bukan karena hidayah dan cinta kepada Nabi Saw, melainkan karena suatu tujuan tersendiri, dan itu ia ungkapkan dalam suatu hadis yang

${ }^{24}$ Departemen Agama RI, Al-Qur'an dan Terjemah, (Jakarta: Almahira, 2015), h. 19.

${ }^{25}$ Wahidul Anam, Dekonstruksi Kaidah 'Adalah al-Shahabah Implikasinya Terhadap Studi Ilmu Hadis, h. 154.

26Wahidul Anam, Dekonstruksi Kaidah 'Adalah al-Shahabah Implikasinya Terhadap Studi Ilmu Hadis, h. 184. 
tercantum dalam Shahih al-Bukhari, sebagai berikut:

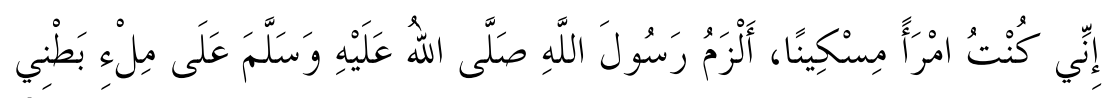
Artinya:

"Aku ini orang miskin, aku bergabung dengan Nabi Muhammad Saw untuk mengisi perut."27

Berdasarkan uraian di atas, bahwa di kritiknya Abu Hurairah oleh Abu Rayyah yang keadilannya masih diragukan dalam periwayatan, maka secara tidak langsung hal itu menjadi penjelas bahwa sebenarnya Abu Rayyah juga masih belum sepakat akan adanya kaidah adil pada seluruh sahabat. ${ }^{28}$

\section{Kesimpulan}

Wahidul Anam merupakan seorang tokoh kontemporer yang ahli dalam berbagai bidang, termasuk salah satunya ialah dalam bidang hadis. Kontribusi beliau dalam bidang hadis dituangkan dalam buku "Dekonstruksi Kaidah 'Adalah alShahabah Implikasinya Terhadap Studi Ilmu Hadis." Dengan menggunakan metode Deskriptif yakni menjelaskan kembali definisi-definisi yang berkaitan dengan konsep keadilan sahabat, baik dari definisi para ulama klasik, kontroversial dan ulama-ulama kontemporer atau para pemikir modern yang memberikan pandangannya mengenai kaidah keadilan sahabat. Dalam mendeskripsikan definisi-definisi yang dipaparkan dalam buku, mengungkap pandangan atau pendapat-pendapat para ulama digunakan pendekatan teologis-normatif dan

27Muhammad bin Isma'il Abu 'Abdullah al-Bukari al-Ju'fi, Shahih alBukhari, (Cet 1;Arab: Dar Tuq an-Najah, 2000), h. 108.

28Wahidul Anam, Dekonstruksi Kaidah 'Adalah al-Shahabah Implikasinya Terhadap Studi Ilmu Hadis, h. 193. 
pendekatan sejarah untuk mempelajari lebih mendalam mengenai kaidah keadilan sahabat. Mulai dari ulama yang menerima kaidah keadilan seluruh sahabat maupun ulama yang menolak kaidah tersebut. Adapun terbongkarnya kaidah keadilan sahabat berdasarkan ketiga pendapat yang disebutkan di atas bahwa konsep adil pada seluruh sahabat terdapat pertentangan dalam penerapannya, meskipun pada umumnya konsep tersebut sudah dianggap final. Namun, ketiga pendapat yang disebutkan di atas yakni kaum Syi'ah, Ahmad Amin dan Mahmud Abu Rayyah memiliki pandangan yang sama. Mereka masih menolak konsep kaidah adil pada semua sahabat. 


\section{DAFTAR PUSTAKA}

Agama Departemen RI. Alquran dan Terjemah. Jakarta: Almahira. 2015.

Anam, Wahidul. Dekonstruksi Kaidah 'Adalah al-Shahabah Implikasinya Terhadap Studi Ilmu Hadis. Yogyakarta: PT Lkis Printing. 2016.

Ismail, M Syuhudi. Kaedah Keshahihan Sanad Hadis, Telaah Kritis dan Tinjauan dengan Pendekatan Ilmu Sejarah. Jakarta: PT Bulan Bintang. 1995.

Ismail, M Syuhudi. Metodologi Penelitian Hadis Nabi. Jakarta: PT Bulan Bintang. 1992.

al-Ju'fi, Muhammad bin Isma'il Abu 'Abdullah al-Bukari. Shahih al-Bukhari. Arab: Dar Tuq an-Najah. 2000.

bin Muhammad, Ahmad bin Abdurrahman. al-Fathu ar-Ribani Musnad al-Imamu ahmad bin Hanbal. Arab: Ihya alTurasi. T.t.

Munawwir, Ahmad Darson. Al-Munawwir Kamus ArabIndonesia. Surabaya: Pustaka Progressif. 1997.

Muslim, Bukhari. Dari Keadilan Sahabat Dan Kemaksuman Imam Hingga Validitas Hadis: Kajian Paradigma Dua Mazhab Besar Islam. Makassar: Lembaga Ladang Kata. 2018.

Phoenix, Tim Pustaka. Kamus Besar Bahasa Indonesia. Jakarta Barat: PT Media Pustaka Phoenix. 2010.

al-Qaththan, Sayikh Manna'. Pengantar Studi Ilmu Hadis. Jakarta Timur: Pustaka al-Kautsar. 2016.

ash-Shiddieqy, Teungku Muhammad Hasbi. Sejarah \& Pengantar Ilmu Hadis. Semarang: PT Pusataka Rizki Putra. 2009. 